Available online at: https://researchsynergy.org/ijmesh/

International Journal of Management, Entrepreneurship, Social Science and Humanities (IJMESH)

ISSN 2580-0981 (online)

Volume 4 Number 2 (2021): 193-203

\title{
Lived Experiences on Varied Dimensions of Police Recruits' Training and Practice Basis for Quality Police Performance
}

\author{
Julieta R. Magpantay', Alberto D. Yazon², Consorcia S. Tan³, Lerma P. \\ Buenvinida ${ }^{4}$, Marcial M. Bandoy 5 \\ 1, 2, 3, 4, 5 Laguna State Polytechnic University, Philippines
}

\begin{abstract}
Police malpractice, abuse of power, and police misfits are issues and problems associated with police recruits. There were reports about inappropriate acts committed by newly hired police officers during their actual field practice. This qualitative phenomenological study determined the dimensions of training that hamper the development of knowledge and skills of the police trainees and police officers. Seventeen (17) purposely selected participants comprised the sample for this study. They were chosen through the following inclusion criteria: police supervisors, trainers, police recruits, staff from the National Police Training Institute (NPTI) and have two or more years of experience. Thirteen recurring themes emerged from the verbatim interviews. The Philippine National Police (PNP), National Police Training Institute (NPTI), and the National Police Commission (NAPOLCOM) are the three public safety institutions in the Philippines that are expected to promote the quality performance of police recruits in both training and practice. On the whole, the results of this study can serve as the basis for creating innovative policies about police recruits' selection, curriculum development, stress management, creation of core competency framework, performance evaluation system, and training and practice needs assessment.
\end{abstract}

Keywords: Lived Experience; Police Recruits; Training and Practice; Quality Police Performance.

\section{INTRODUCTION}

This is an open access article under the CC-BY-NC license.

Police malpractice is a global phenomenon. The aberrant activities of some police officers include police brutality and corrupt practices, namely, harassment, accepting bribes, money extortion, planting evidence, and violation of human rights. The presence of police officers, who violate their solemn oath as a peacekeeper, cause fear about public safety. More so, with the rising numbers of police officers who are abusive of their authority, police organizations' credibility worldwide is at stake. The task nowis to pinpoint the reasons why police officers commit immoral and illegal actions. Police organizations and other agents for peacekeeping in the community should address issues and problems caused by police who are misfits as public safety officers.

In the Philippines, there are, more or less, 1,700 personnel who were accused of having committed immoral and illegal activities. One such prominent case was the sexual assault of a 14-year-old inside a police station. The girl was promised that her parents, involved in illegal drugs, shall be released from prison (Recuento, 2018). Another case was the kidnapping and rape of two people. This was committed by 11 police officers with the ranks of P01 to P03. This incident happened during an alleged anti-narcotics operation in Pasay City. Still, another was the rape of a woman by a desk officer inside the Manila Police District (MPD) headquarters on December 31, 2010, and the shooting spree of a police officer in Bulacan, killing 1 person and injuring 2 others (Canoy, 2011). There was also the case of Kian Lloyd Delos Santos, who was incorrectly identified by an informant and killed by the police (Sullivan, 2018). Finally, the report of the involvement of three officers in abducting and killing of a South Korean businessman (Morella, 2017).

The massive criminal activities done by men in uniform in the Philippines lead to negative public sentiments. People's complaints were heard in various mediums, namely, radio, television, and even 
International Journal of Management, Entrepreneurship, Social Science and Humanities (IJMESH), Vol. 4 (2), 193-203

Lived Experiences on Varied Dimensions of Police Recruits' Training and Practice Basis for Quality Police

Performance

Julieta R. Magpantay; Alberto D. Yazon; Consorcia S. Tan; Lerma P. Buenvinida; Marcial M. Bandoy

on the streets. The Philippine National Police (PNP) need to answer the following: What actions are being done to stop police officers from committing unwarranted acts? What kind of training or recruitment process do these police officers have? What assurance can the PNP give to the people that that police who are misfitsin service will be dealt with appropriately? Pelayo (2018) reported that the PNP had recommended dismissal from service of 15 police officers for violating RA 9745 or the Anti-Torture Act of 2009 charged a total of 674 officers between July 2016 and May 2018 and fired, suspended, and demoted 19.

A study by Jensen and Hapal (2018) established the relationship between moneyand violence in the Philippines connected with the war on drugs. The authors argued that illegal practices and killings committed by police officers are associated with the rampant corruption in the Philippine police. The authors conclude that there is a direct relationship between state regulations and police corrupt practices in terms of criminal justice, the prison system, anti-corruption, and the war on drugs. This study recommends the following: (1) Conduct performance appraisal of all personnel in the PNP in terms of both quantitative and qualitative work efficiency; and (2) Provide on-the-job training that could augment the skills and competencies of the police (Human Resources Management, Performance Appraisal, 2013, Noe; Silverman, 2009).

The researcher has decided to conduct this phenomenological study for two reasons: first, there were no sufficient empirical studies on the subject of police recruits; and second,perspectives of the research participants can contribute to the enhancement of training programs and activities under the management of the Philippine National Police Institute (PNTI) and police stations within the CALABARZON region.

The outcome of this study can contribute to the enhancement of police recruits training as well as efficient and effective police practice under the following institutions and organizations: (1) PNP The results from this study could offer some valid information to help the leadership design innovative program on training or re-training of police officers about knowledge enhancement and skills development; (2) NAPOLCOM This study may offer sound recommendations that may help the management to improve the qualification standards for recruitment and selection of applicants to police service; (3) National Police Training Institute This study may offer recommendation on redesigning its training program in terms of curriculum, facilities, equipment, teachers' qualification, police recruitment process, among others; and (3) Police Stations This study may offer recommendations on the enhancement of programs and activities in terms of stress management, police supervision, and management and enhancement of the image of the police in the eyes of the community.

\section{Objectives of the Study}

This study determined the perspectives of 17 research participants regarding the various dimensions of police recruits' training and field practice. The goal is to offer recommendations to the National Police Training Institute (NPTI), National Police Commission (NAPOLCOM), and Police Stations in the CALABARZON regiontoward quality police service.

Specifically, this study answered the following questions: What are the perspectivesof the research participants on the quality of police recruits as contributed by police training? What are the perspectives, opinions, and experiences of the research participants on the quality of police recruits as manifested in their practice? How could police trainingbe improved? How could police recruits' field practice be improved?

\section{LITERATURE REVIEW}

A strong spiritual foundation is an important dimension in building the values and image of the 
International Journal of Management, Entrepreneurship, Social Science and Humanities (IJMESH), Vol. 4 (2), 193-203

Lived Experiences on Varied Dimensions of Police Recruits' Training and Practice Basis for Quality Police

Performance

Julieta R. Magpantay; Alberto D. Yazon; Consorcia S. Tan; Lerma P. Buenvinida; Marcial M. Bandoy

police (Smith and Ginger, 2010). This is because spiritual development is an effective means of protecting officers from succumbing to corrupt practices in many police organizations around the world (Chopko, Facemire, Palmieri, and Schwartz, 2016; Shapland, Crawford, Gray, and Burn, 2017). The Enhanced Revitalized Internal Cleansing Strategy (ERICS) was introduced to create a Godcentered, Service-oriented, and Family-based organization by instilling values creation, spiritual growth, and strengthening of PNP personnel's families (PNP, 2019). In order to ensure the effectiveness of the spiritual component of police practice, Kramer (2019) recommends that PNP personnel should observe the ethical practice of their profession through the following: observe impartiality, avoiding, profiling, protecting citizens' rights, determining the necessary amount of force, and police officers' maintaining principled lifestyles outside of their work. Patel (2018)termed these as "consequentialist" perspectives' which he cited from (McCarthy and Parent, 2016). There is a need for police officers to maintain ethical practice or else face the consequences of their aberrant actions.

Police supervisors' ability to solve the problem is correlated with their ability to prioritize their actions. This was the conclusion derived by Mastrofski and Parks (2019), who did a survey on how police recruits perceive the attitudes of their superior officers regarding problem-solving. On the other hand, the study of Bonnin (2008) and Banks (2017) revealed that problem-solving is not the sole responsibility of police supervisors. It is because the attitude of the police subordinates affects the ability of their superiors to handle and solve problems. These authors conclude that both police superiors and subordinates should know how to set priorities in solving problems. Banks (2017) promotes imposing disciplinary measures on those police officers who can't and will not participate in solving issues in police practice. The leadership of the PNP emphasizes punishment as a form of disciplinary measure. Hence, has dismissed 72, demoted 20, and suspended 31 police officers because of their criminal records (Talabong, 2017). In order to promote discipline, police recruits' performance needs continuous monitoring and observation (Behavioral Insights, 2015).

Basinska, Wiciak \& Daderman (2014) state that policing is a profession often associated with stress or the condition in which the human system response to changes. Police work causes serious stress that leads to the occurrence of mental and physical health problems; hence, it is important that stress management becomes a regular program in both training and practice (Anshel and Brinthaupt, 2014; Mishra, 2014; Choudhary and Madnawat, 2014; and De Terte, 2014). Brooks (2020) says that the highly militarized form of training that focuses more on the use of firearms, self-defense, and the application of force tactics creates stress in training and practice (Brooks, 2020). However, highly militarized training is not a sole indicator of stress development. In the Philippines, other stressproducing dimensions are as follows: resource capability, training equipment, training facilities, implementation of merit and demerit system, barracks' ventilation, weak implementation of the disciplinary system; lack of reading materials, and lack of competent instructors (PNP, 2019; Dallas Police, 2018; Police Executive Research Forum, 2015).

In order to improve training, curriculum development is important (Organization for Security and Cooperation in Europe, or OSCE, 2019). Curriculum development should center on the acquisition of core competencies such as use good judgment, capacity for empathy and compassion, capacity for multi-tasking, ability to demonstrate courage and to take responsibility, demonstrate assertiveness, demonstrate integrity, capacity for engagingin teamwork, and ability to collaborate (Krumie, M., 2015; Roberts, 2012; Queensland Police Service, 2012; Roufa, 2017). Furthermore, the Training curriculum should contain clear objectives with balance in both theories and practical application of knowledge. Teachers' qualifications and the strategies they use are likewise important (Littell, 2017; Eitle, Stewart, and Stolzenberg, 2014).

\section{RESEARCH METHOD}


International Journal of Management, Entrepreneurship, Social Science and Humanities (IJMESH), Vol. 4 (2), 193-203

Lived Experiences on Varied Dimensions of Police Recruits' Training and Practice Basis for Quality Police

Performance

Julieta R. Magpantay; Alberto D. Yazon; Consorcia S. Tan; Lerma P. Buenvinida; Marcial M. Bandoy

\section{Research Design}

The purpose of this study was to describe and analyze the perspective of 17 participants who were purposively selected based on the following criteria: who have experience either as police trainers, police officers in managerial positions, police recruits, and members from non-governmental organizations whose concern is on peace and order. Two general types of questions, namely, Textural or What and Structural or How to guide the development of the interview guide (Creswell and Poth, 2018). The answers to these question were determined through a qualitative phenomenological approach that describes the meaning for several individuals of their lived experiences regarding a concept or idea. In phenomenology, the researcher transcends or suspends her past knowledge and experience to understand the phenomenon. It is important for the researcher to explain what prompts her interest in conducting the study (Creswell and Poth,2018; Marcom, 2010). The researcher has decided to conduct this study because of her desire to seek solutions to problems connected with police recruits' performance in training and in practice. As a police officer as well as a trainer herself, she has observed and experienced problems connected with her professional practice.

\section{Data Collection and procedure}

After approval from the University's Institutional Review Board and the heads of respective police stations and offices of the National Police Training Institute (NPTI), persons who have met the inclusion criteria were approached and asked to participate.The participants were asked to read and sign an "Informed Consent Letter". This letter contains the purpose of the study, role as participants, and the strict observance of ethical conduct of research which includes non-disclosure of their names in the manuscript. The participants received an interview guide through their respective email account. The practice of face-to-face interviews was not done due to the observance of social distancing. The participants opted to write their answers and sent the answered form through email. After responses were transcribed, participants who were not able to answer all questions and those that gave unreadable answers were contacted, and their answers were verified.

\section{Data Validation and Analysis}

There were three sources of validation for this phenomenological research. This is called corroborating through triangulation or the use of multiple data sources. Creswell (2018) listed the three sources of data validation and analysis, namely, researcher's lens, participants' lens, and reviewers' lens. These validation strategies are explained below.

The Researcher's Lens. As a police officer herself who has been serving the police organization for 3 decades, the researcher has first-hand observation and experiences on the limitations, difficulties, and inefficiencies of many new police recruits when it comes to the extent of their knowledge on the rudiments and requirements of good policing, their apparent manifests of lack of skills in performing the tasks required of them along observing police protocols and procedures and the lack of an appropriate behavioral attitude towards professionalism as police officers.

Participant's Lens. The second source for validation was from the participants. After data had emerged and subsequent findings, feedbacks were sought from the 17 research participants. The purpose was to establish the participant's views of the credibility of the findings and interpretation. The participants play a critical role because they are asked how well the ongoing data analysis represents their experiences (Hays \& Singh, 2012 as cited in Creswell, 2018 p. 261). For this strategy, the researcher individually approached each of the participants and asked them for the accuracy of recording and interpretation of their individual responses. 
International Journal of Management, Entrepreneurship, Social Science and Humanities (IJMESH), Vol. 4 (2), 193-203

Lived Experiences on Varied Dimensions of Police Recruits' Training and Practice Basis for Quality Police

Performance

Julieta R. Magpantay; Alberto D. Yazon; Consorcia S. Tan; Lerma P. Buenvinida; Marcial M. Bandoy

Reviewers' Lens. In this approach, the researcher sought the support of an external consultant (not from the PNP or from the NPTI) to examine both the process and the product of the study. One important consideration for this approach is that the reviewer should have no connection with this study (Merriam and Tisbel, 2015). In assessing the product, the auditor examined whether the findings, interpretations, and conclusions were supported by the data. The Chief of PNTI Research Management Group served as a validator.

\section{Data Analysis}

Moustakas (1998), as cited by Creswell and Poth (2018) phenomenological method was employed in analyzing participants' transcripts. In this method, the written transcripts were read several times to obtain an overall feeling for them. From each transcript, significant phrases or sentences that pertain directly to the lived experiences of the participants were identified. Meanings are then formulated from the significant statements and phrases. The formulated meanings were clustered into themes. After this, the researcher approached some of the participants a second time and validated the findings. One of the limitations in data gathering was caused by the observance of social distancing. Hence, data gathering was done for two weeks only, through social media means like messenger, Facebook, and e-mail.

\section{FINDINGS}

The interview of the 17 research participants resulted in 68 verbatim transcripts from which 91 significant statements emerged. The significant statements were individually analyzed in order to establish interpreted meaning. Thirteen recurring themes wereidentified. The following results are arranged according to the problem or questions sought. The first was on the varied dimensions of training that contribute to the quality of police recruits' outcomes. The dimensions covered were quality training, the competence of the recruits, facilities and equipment, and teachers and teaching strategies.

On the general observation of the training and its environment, a total of 11 significant statements were revealed as issues or problems. These cover values, supervision, body movements, human rights, military-like mentality, short duration of training, command system, use of force, and physical activities.

On the other hand, the issues or problems about police recruits' competence center on actual experience, support system, discretion, learning from mistakes, lack of job description, curriculum review, knowledge application, community policing, and non-focus on a humanistic approach.

Furthermore, regarding the environmental condition, issues and problems have been identified related to modern-day policing, congestion, model in police training, lack of good training facilities, poor online service, and problems in housing recruits.

Finally, in terms of teachers and teaching strategies, problems are connected with class participation, large class, the training period is short, communication and voice projection,updates on knowledge on scientific and laws, observance of COVID protocol, and expertise on the subject taught. The second question centered on the quality of police recruits as manifested during actual field practice. The findings revealed that many police recruits have issues or problems connected with law enforcement, human relations, technical expertise, educational qualification, field exposure, firearms management, environmental condition, use of gadgets, bad decisions, non-admission of lack of competence, more on theory, bad police image, observance of police operational procedure and judicial process, poor computer know-how, improper report and format, lack of field exposure, lack of community-building skills, no modeling and too much concentration on physical activities. 
International Journal of Management, Entrepreneurship, Social Science and Humanities (IJMESH), Vol. 4 (2), 193-203

Lived Experiences on Varied Dimensions of Police Recruits' Training and Practice Basis for Quality Police

Performance

Julieta R. Magpantay; Alberto D. Yazon; Consorcia S. Tan; Lerma P. Buenvinida; Marcial M. Bandoy

The third problem sought answers on how to improve the delivery of police recruits' training. The participants offered the following recommendation; namely, enhancement of trainees' creativity, personal improvement, showing good role models through good leadership, doing the background check, conducting needs analysis, imposing disciplinary measures, and promoting program sustainability.

The fourth and last question was on how to improve police recruits' field practice. Theparticipants have offered the following recommendation, namely, develop a balanced curriculum as to the content, increase the duration of the training, get trainers with policing experience, address malpractices, increase manpower, and observe decorum.

From the above significant statements, the researcher culled 13 recurring themes as follows: police malpractice, moral values and reform, ethical practice and human rights, supervision and role modeling, observation and behavioral management, the stress in training and practice, militarized training, a curriculum plan, and capability building, facility, equipment and teaching aids, core competencies and soft Skills, theories and practice, teachers' qualification and strategies; competency framework and performance evaluation;and needs analysis for training enhancement.

\section{DISCUSSION}

The lack of sound moral values contributes to attitudinal issues in both training and practice. Thus there is a need for spiritual reform. The possession of sound values and strong spirituality of police recruits contribute to countering the negative impact of traumatic and other workrelated stressors on the health of police officers (Recuento, 2018; Chopko, Facemire, Palmieri, and Schwartz, 2016). There is a connection b e tw e e $\mathrm{n}$ how the community treats police and how the police treat the community (Giger, 2010). This was attributed to a lack of professionalism in police practice. In order to solve this, the PNP should scout for specialists is or experts who can offer recommendations on how to improve the restoration program of the Agency (Shapland, Crawford, Gray, and Burn,2017).

The issues of lack of ethical practice and non-observance of human rights are two of the major criticisms on police performance not only in the Philippines but worldwide. Other factors about police malpractice are ethical dilemmas on profiling, impartiality, making shortcuts, and questionable lifestyles. There are challenges as well, like police operations' credibility in relations with drug cases, use of lies, deception, and tricks wherein the investigators perform role-playing acts just to get a confession (Kramer,2018; Patel, 2018; McCarthy and Parent, 2016; Gravel, 2018). Important to training police recruits, especially inside a training camp like the NPTI is good supervision and role modeling. However, when trainers and police supervisors fail in these, then the mission and goals of the PNP can't be achieved (Mastrofski S.D, Parks R. B., et al., 2013).

The use of observation as a tool for managing behavior was emphasized by the Behavioral Insights Team (2015), who did a country-wide survey in the United Kingdom about the reason why people enter the law enforcement profession. A total of 11, 994 comprised the sample for this study. The top answers are the following: to serve the community, to meet the physical and intellectual challenges, to contribute to changing the image of the police and to fight criminality.

Law enforcement is a profession associated with stress. Police officers encounter stressors starting from their training, namely gender bias, highly militarized training instruction where obedience to authority and higher up is done without questioning. Stressors continue more so during police recruits' actual practice, where they face highly challenging situations which are most of the time life- 
International Journal of Management, Entrepreneurship, Social Science and Humanities (IJMESH), Vol. 4 (2), 193-203

Lived Experiences on Varied Dimensions of Police Recruits' Training and Practice Basis for Quality Police

Performance

Julieta R. Magpantay; Alberto D. Yazon; Consorcia S. Tan; Lerma P. Buenvinida; Marcial M. Bandoy

threatening. Stress is a significant predictor of mental health (Basinska, B. A., Wiciak, I., \& Daderman, A. M. 2014; Anshel \& Brinthaupt, 2014; Bagutayan, 2015).

Stressors affect the mental health of law enforcers. This is why controlling the situations is important and necessary for survival in police work. Hence, police officers must know how to cope with stressors. The management of stress and the development of adaptive coping strategies can be done by observing how others survive in the profession. However, it is not just coping but the development of an individual's psychological resilience. This means that despite the experienced difficulties, police officers can grow and develop in the practice of the law enforcement profession (Mishra, 2014; Choudhary and Madnawat, 2014; De Terte et al., 2014).

Police training must adapt to the challenges of the community policing era,however, 90 percent of training is spent on firearms, self-defense, and other use of force. This is why police recruits' training has not caught up with the relevant acquisition of knowledge in terms of building community relations, ability to solve the problem, occupational socialization, sharing with the community the challenges of maintaining public safety, understanding racial issues, police strategies and duties, observance of transparency, and how to deal with media. Some problems connected with the acquisition of knowledge are resource capability, training equipment, training facilities, implementation of merit and demerit system and barracks ventilation, weak implementation of the disciplinary system, lack of reading materials, and lack of competent instructors. (Dallas Police, 2018; Police Executive Research Forum, 2015, Anson, 2006).

The highly militarized training orientation is one of the reasons why some police recruits fail to develop holistic competency in various aspects of policing. This training orientation, as mentioned by Varona (2010), contributes to corruption in police service, political influences, and patronage politics, and human rights abuses. Brooks (2020) explained how these corrupt practices occur. He listed some unwarranted activities in police recruits training such as drill and formation, standing at attention when senior officers enter the room, and proper boot-polishing method. Devotion to duty is given little priority as compared to the previously enumerated details.

Curriculum planning is essential in any educational process and training. Failure to come up with a good curriculum plan would most often lead to failure in accomplishing the vision and mission of an educational institution. Police capability and competence should cover law and order, traffic authority and control traffic and transport, community policing, crime response, recognize unlawful acts, detect offenders and properly use police powers, aid and assist in emergencies of all kinds and in the event of a major threat provide information and help to those in need of assistance (Organization for Security and Cooperation in Europe, 2009).

Crucial to the curriculum plan is the recruitment process (Burdock, 2013; Cappitelli, 2018). In the Philippines, despite clear guidance on what kind of police should be recruited in the police force, problems are manifested like police brutality and incompetent response to crime. One of the causative factors is the insufficiency of training that significantly contributes to poor quality products (Balmores, 2017). In response to this, the PNP has mandated that all specialized and competency courses/training with a maximum of 10 days duration are required to undergo the Course Certification to determine the readiness and completeness of the course (PNP, 2019).

The long-standing problems in police training institutions in the Philippines are insufficient equipment, not-so-well-maintained facilities, and lack of teaching aids. In order to solve these problems, the Philippine National Police crafted a Master Plan known as Digital Transformation Roadmap or the PNP DTR. This roadmap serves as a guide in harmonizing the use of mobile 
International Journal of Management, Entrepreneurship, Social Science and Humanities (IJMESH), Vol. 4 (2), 193-203

Lived Experiences on Varied Dimensions of Police Recruits' Training and Practice Basis for Quality Police

Performance

Julieta R. Magpantay; Alberto D. Yazon; Consorcia S. Tan; Lerma P. Buenvinida; Marcial M. Bandoy

technology in order to facilitate effective and efficient crime prevention and crime solution services to external and internal stakeholders of the Philippine National Police (PNP, 2019).

The acquisition of core competencies is basic to all educational and training schools. These competencies are on knowledge and skills necessary for efficient and effective performance as what the job requires. In the Philippines' training schools, thereis an imbalance in learning content. There is more focus on the development of skills at combat techniques while negating other necessary skills like conflict management through non-threatening that includes human relations and ethical practice. Under human relations, important skills include capacity for empathy, ability to demonstrate courage, take on responsibility, ability to show initiative, demonstrate assertiveness, capacity to engage in teamwork, and ability to collaborate. Important to these core competencies are the skills in communication, computer application, interviewing. These skills are important to build a case and to obtain reliable information (Krumie, M., 2015; Roberts, 2012; Queensland Police Service, 2012; Roufa, 2017).

Given that training of police recruits was conducted in six months only, the training modalities concentrated more on theories rather than application. This teaching approach is not desirable for those non-Criminology graduates. This condition gives riseto an imbalance between theories and practice. Jaso (2007) disclosed the following problems encountered by the trainees as (1) lack of connection between competencies and skills; (2) lack of coordination between partner industries (criminal justice system); (3) no work plan clearly presented on the trainees along with training requirements, expected performance, and placement for work; (4) lack of supervision on the trainees' performance; and, (5) lack of identified local resources.

Mager (2005) said that setting clear objectives is important for a training program because, with clearly stated objectives, the actions of the participants become focused. In addition, when trainers know the objectives, they can communicate them to employees participating in the program. Finally, down the road, establishing objectives provides a basis for measuring whether the program will succeed. Training objectives can be effective if the following conditions are met: (1) a statement of the employees' performance or outcome; (2) a statement of the quality of level of performance that is acceptable; (3) a statement of how to apply what he or she learned; and (4) if possible objectives should identify resources required to carry out the desired objectives.

Trainers are recipients of blunt criticisms on the failure of the police recruits to perform. Breiser (2003) said that highly qualified teachers use varied teaching strategies. Police training, in particular, should be handled by teachers who are experts not only in behavioral approaches but more on utilizing evolving police practice under the axiom of community policing. In addition to expertise on the subject matter, well-trained teachers should also be skillful at applying motivational and reinforcement techniques in learning. Differential Reinforcement theory explains that behavior learned is reinforced negatively or positively through the influence of other people (Kahayon, 1989; Littell, J. (ed), 2017).

\section{CONCLUSION}

The establishment of a highly standardized training program for police recruits is critical for producing a credible police force in the Philippines. In the teaching context, the professional object of teachers is police recruits' learning, particularly on core subjects of police practice. On the other hand, in the practice context, the object is police performance that promotes quality community and police relationship, good case management manifested with the absence of corrupt or corruptible orientations. The findings from this study point to several dismal situations experience not only by the trainees but also the training managers and teachers or instructors. There are 13 problem areas that need program or service enhancement. These areas include moral and spiritual values, ethical and professional practice and human rights, supervision and role modeling, performance 
International Journal of Management, Entrepreneurship, Social Science and Humanities (IJMESH), Vol. 4 (2), 193-203

Lived Experiences on Varied Dimensions of Police Recruits' Training and Practice Basis for Quality Police

Performance

Julieta R. Magpantay; Alberto D. Yazon; Consorcia S. Tan; Lerma P. Buenvinida; Marcial M. Bandoy

modification, observation as a tool, stress management, soft skills and community policing, a humanistic orientation, curriculum development, facility and equipment, the recruitment process for both trainees and teachers alike and training needs assessment.

The results and findings offered here have implications to the PNP and its training institutions along the dimensions of policy and curriculum development, stress and behavioral management, promotion of discipline and punishment for erring officers, enhancement of the recruitment process, upgrade of technical systems to adapt to modern policing; and continuous monitoring of programs and activities towards sustained quality training and practice.

The Philippine National Police (PNP), National Police Training Institute (NPTI), and the National Police Commission (NAPOLCOM) are the three public safety institutions in the Philippines that should institute measures to promote the quality performance of police recruits in both training and practice. On the whole, the results of this study can serve as the basis for creating innovative policies about police recruits' selection, curriculum development, stress management, creation of core competencies framework, upgrade of performance evaluation system in training and practice, and needs assessment.

\section{LIMITATION \& FURTHER RESEARCH}

The use of qualitative phenomenological research design was delimited to getting perspectives from 17 participants only. If the entire population of police officers is considered, there is a need to do a similar study by using a larger sample through a descriptive survey design. This may include participants from other areas in Region 4A, Philippines. The condition of social distancing due to pandemics was a major contributory factor for the choice of research method.

\section{REFERENCES}

Anshel, M. H., \& Brinthaupt, T. M. (2014). An exploratory study on the effect of an approach-avoidant coping program on perceived stress and physical energy among police officers.Psychology, $5(1), \quad 676-687$.

doi:10.4236/psych.2014.57079

Banks, C. (2017). Criminal Justice Ethics. London: Sage Publications, pp. 48-51 Behavioural Insights Team (2015) Behavioural Insights for building the police force for

tomorrow. United Kingdom. https://www.bi.team/wp- content/uploads/2019/01/BITPolice-report_MKV5-WEB.pdf. Retrieved on March 15, 2021.

Baqutayan, S. S. (2015). Stress and coping mechanisms: A historical overview. Mediterranean Journal of Social Sciences, 6(2), 479-488.

doi:10.5901/mjss 2015.v6n2s1p479

Basinska, B. A., Wiciak, I., \& Daderman, A. M. (2014). Fatigue and burnout in police officers: The mediating role of emotions. Policing: An International Journal of Police Strategies \& Management, 37(3), 665-680. doi:10.1108/PIJPSM-10- 2013- 0105

Bonnin,l D. (2008). The Problem of Punishment, Cambridge, England, University Press (as cited in Banks, c., 2017, pp. 145-156).

Brooks, R. (2020).Stop training police like they're joining the military. heatlantic.com/ideas/archive/2020/06/police-academies-paramilitary/612859/.

Retrieved April 12, 2021.

Burdock, J. (2013) Wide Reaching Benefits of Law Enforcement Training. https//www.leb.fbi.gov.com. Retrieved on November 20, 2020.

Choundary (2014). Predictors of mental health and happiness in government and private schools. Indian Journal of Health and Wwell-Being, 5 (1): 19-23.

De Terte, I., Stephens, C., \& Huddleston, L. (2014). The development of a 3-part model of psychological resilience. Stress and Health: Journal of the International Society for the Investigation of Stress, 30(5), 416-424. doi:10.1002/smi.2625

Canoy, J. (2011) Crimes by cops batter PNP image. ABS-CBN News. https://news.abs- 
International Journal of Management, Entrepreneurship, Social Science and Humanities (IJMESH), Vol. 4 (2), 193-203

Lived Experiences on Varied Dimensions of Police Recruits' Training and Practice Basis for Quality Police

Performance

Julieta R. Magpantay; Alberto D. Yazon; Consorcia S. Tan; Lerma P. Buenvinida; Marcial M. Bandoy cbn.com/nation/01/05/11/crimes-cops-batter-pnp-image. Retrieved on October, 25, 2019.

Cappitelli (2018). 5 of the biggest issues facing law enforcement in 2019.

https://www.police1.com/2018-review/articles/5-of-the-biggest-issues-facing- law-enforcementin-2019-Nfo4Fin1vBoTwFJS/. Retrieved on November 12, 2020.

Chopko, B., Facemire, V., Palmieri, P. and Schwartz, R. (2016). Spirituality and health outcomes among police officers: empirical evidence supporting a paradigm shift. Available at:

https://www.tandfonline.com/doi/abs/10.1080/1478601X.2016.1216412 Creswell, J. and Poth, C. (2018). Qualitative Inquiry and Research Design. Thousand

Oaks, CA: Sage

Dallas Police (2018) Challenges of Police Training In the Community Policing Era. http://www.communitypolicing.com/challenges-of-police-training-in-the- communitypolicing-era. Retrieved on November 13, 2020.

Eitle, D., Stewart, J., Stolzenberg, L. (2014) The Effect of Organizational and Environmental Factors on Police Misconduct https://journals.sagepub.com/doi/abs/10.1177/1098611114522042

Jensen S. and Hapal, K. (2018). Police Violence and Corruption in the Philippines: Violent Exchange and War on Drugs. Journal of Current Southeast Asian Affairs, 37, 2. German Institute of Global and Area Studies. http://nbn- resolving.org/urn:nbn:de:gbv:18-4-11264 ISSN: 18684882 (online), ISSN: 1868-1034. Retrieved on January 15, 2020.

Gravel, S. (2018). Common Mistakes in Drug Crime Cases. Available at: https"//www.michigan-drugattorney.com

Kaliyaperumal, K. (2020). Guideline for Conducting a Knowledge, Attitude. resource.org/content/files/guideline_kap_Jan_mar04.pdf

Kramer L. (March 20, 2018) Ethical Issues in Criminal Justice. Available at: https://legalbeagle.com.

Littell, J. (ed.) (2017) Relationship between teacher qualification and the quality of education and Campbell Systematic Reviews, USA. https://files.eric.ed.gov/fulltext/ED573516.pdf. Retrieved on April 6, 2021.

Mastrofski S.D, Parks R. B. et.al (20013). Police officers' attitudes, behavior, and supervisory influences: An analysis of problem solving. Criminology 41 (1) p. 200.

McCarthy and Parent (2016) Ethical Issues during an Investigation. Available at: Https://opentextbc.ca

Mishra P. K. (2014). Stress and coping: some critical issues. Indian Journal of Positive Psychology, 5 (3): 341-343

Morella, C. (2017) Long history of corruption in Philippine police force. Agence France- Presse. Https://news.abs-cbn.com. Retrieved on October 25, 2019.

OSCE (2009) The Good Practices in Basic Police Training. https://www.osce.org/files/f/documents/a/2/109933. Retrieved April 6, 2021.

Pajarillo-Guadamor, L. (2016). Qualifications and Preparedness of Police officers in sustaining peace and Order: Its Implications to Quality Service. International Journal of Advanced Research in ISSN: 2278-6236 Management and Social Sciences Impact Factor: 6.284 Vol. 5 | No. 2 |

Patel, C. (February 25, 2018). In Examining the Philippines' Drug War, the ICC Takes a Positive but Challenging Step. Available at: https://www.chathamhouse.org

Pelayo, M. (2018). Criminal charges ordered vs 15 cops linked to human rights abuses. https://untvweb.com/news/criminal-charges-ordered-vs-15-cops-linked-to- human-rightsabuse/. Retrieved October 25, 2019.

PNP (2019) PNP Annual Accomplishment Report. Pnp.gov.ph. Retrieved April 7, 2021. Police Executive Research Forum (2015). Why Police Community Relationship is

Important. https://www.justice.gov/crs/file/836486/download. Retrieved on November 15, 2020. .

Queensland Police Service (2012). Introduction to Policing. What skills do you need? html. Retrieved November 15, 2020

Recuento, A. (2018). PNP Initiates spiritual reform within its ranks as new strategy in its internal cleansing. Available at: https://news.mb.com.ph/2018/11/24/pnpinitiates-spiritual-reform-within-its-ranks-as-new-strategy-in-its-internal- cleansing/

Roufa, T. (2017). Soft Skills You Need to Be a Successful 
International Journal of Management, Entrepreneurship, Social Science and Humanities (IJMESH), Vol. 4 (2), 193-203

Lived Experiences on Varied Dimensions of Police Recruits' Training and Practice Basis for Quality Police

\section{Performance}

Julieta R. Magpantay; Alberto D. Yazon; Consorcia S. Tan; Lerma P. Buenvinida; Marcial M. Bandoy

Police Officer https://www.thebalance.com/understand-the-dangers-of-being-a-policeofficer- 403499. Retrieved October 21, 2020.

Shapland, J., Crawford, A., Gray, E. and Burn, D. (2017). Restorative justice at the level of police in England: implementing change. Center for Research Universities of Sheffields and Leeds

Silverman S.B. (2007). Individual development through performance appraisal.

Developing Human Resources. New York, USA.

Sullivan E. (2018) 3 Police officers found guilty of murder in Philippines' War on Drugs. https://www.nytimes.com/2018/11/29/world/asia/philippines-duterte-drug-

killings-police.html. Retrieved on October 25, 2019.

Talabong, R. (2018) Policing the PNP: Scalawags spoil Duterte vow to end crime. https://www.rappler.com/nation/207632-pnp-scalawags-spoil-duterte-vow-end- crimePhilippines. Retrieved on October 25. 2019.

van Manen, M. (2014). Phenomenology of practice: Meaning-giving methods in phenomenological research and writing. Qualitative Health Research, 16, 713- 722.

Varona, G. (2010). Politics and Policing in the Philippines: Challenges to Police Reform. Fjhp/volume 26, 2010 page 101.

Xinxua (2018) Philippines kicks out over 2,000 corrupt police from force. http://www.xinhuanet.com/english/2018-08/06/c_137371816.htm. Retrieved on October 25. 2020. 